\title{
A New Look at Transudation: The Apocrine Connection
}

\author{
Robert FARKAŠ ${ }^{1}$, Milan BEŇO ${ }^{1}$, Denisa BEŇOVÁ-LISZEKOVÁ ${ }^{1}$, Ivan RAŠKA ${ }^{2}$, Otakar $^{2}$ \\ RAŠKA ${ }^{2,3}$
}

${ }^{1}$ Laboratory of Developmental Genetics, Institute of Experimental Endocrinology, Biomedical Research Center, Slovak Academy of Sciences, Bratislava, Slovak Republic, ${ }^{2}$ Institute of Biology and Medical Genetics, First Faculty of Medicine, Charles University, Prague, Czech Republic, ${ }^{3}$ Institute of Pathophysiology, Third Faculty of Medicine, Charles University, Prague, Czech Republic

Received June 9, 2019

Accepted December 20, 2019

Epub Ahead of Print March 23, 2020

\begin{abstract}
Summary
Transcellular trafficking in which various molecules are transported across the interior of a cell, is commonly classified as transcytosis. However, historically this term has been used synonymously with transudation. In both cases transcellular trafficking starts with the internalization of proteins or other compounds on the basal or basolateral side of a cell and continues by their transport across the interior to the apical pole (or vice versa) where they are subsequently released. This allows a cell to release products which are synthesized elsewhere. Here, we discuss the common features of both transcytosis and transudation, and that which differentiates them. It appears that transcytosis and transudation are identical in terms of vesicular import and endosomal sorting of cargo, but completely differ in the re-secretion process. Specialized epithelial cells re-release substantial quantities of the endocytosed material, and often also a great variety. Some recent studies indicate that this is achieved by non-canonical apocrine secretion rather than by the regular vesicular mechanism of exocytosis, and takes place only on the apical pole. This massive re-release of endocytosed proteins, and potentially other compounds via the apocrine mechanism should be considered as transudation, distinct from transcytosis.
\end{abstract}

\section{Key words}

Transcellular transport - Vacuolation - Endosome trafficking • Vesicular cargo • Exocytosis • Apocrine secretion • Transcytosis • Transudation

\section{Corresponding authors}

Robert Farkaš, Laboratory of Developmental Genetics, Institute of Experimental Endocrinology, Biomedical Research Center, Slovak Academy of Sciences, Dúbravská cesta 9, 84505 Bratislava, Slovak Republic. E-mail: ueenfark@savba.sk. Otakar Raška, Third Faculty of Medicine, Charles University, Ruská 87, 10000 Prague, Czech Republic. E-mail: raskaota@gmail.com

\section{Introduction}

In contrast to the widely-known and welldefined process of exocytosis, apocrine secretion can be characterized as a non-vesicular transport and noncanonical secretory pathway that entails the loss of part of the cytoplasm. Exocytosis (also known as merocrine secretion), is an intensely studied mechanism of eukaryotic cells with more than two dozen identified factors and their corresponding genes (Jahn 2004, Rutter and Tsuboi 2004, Sudhof 2004, Chieregatti and Meldolesi 2005, Barclay et al. 2005, Snyder et al. 2006, Westerink 2006, Leitzell 2007, Deak et al. 2008, Beck et al. 2009, Südhof and Rothman 2009, Anantharam et al. 2010, He and Guo 2010, Morgan et al. 2013, Murray and Stow 2014, Kokotos and Cousin 2015, Cousin 2017, Milosevic 2018, Anantharam and Kreutzberger 2019, Maj et al. 2019, Zuber and Lučić 2019). Exocytosis is the process relaying on specific membrane contact, priming and fusion events required for the selective release of

PHYSIOLOGICAL RESEARCH • ISSN 1802-9973 (online) 
compartmentalized compounds such as signaling molecules (neurotransmitters or hormones). The exocytotic secretory pathway involves the formation of vesicles in the trans-Golgi in its initial phase, then targeted translocation of these vesicles to sites on the plasma membrane, nucleation, zippering, budding, the preparation of the docked vesicles for full fusion competence (priming), and the subsequent triggered fusion of these membranes, this results in their coalescence and the release of vesicular contents to the extracellular space. In addition to exocytosis which occurs by the targeted fusion of secretory vesicles with the plasma membrane, two additional types of noncanonical secretion exist: apocrine and holocrine. During theses secretions entire pieces of the cell are released and homotypic membrane fusion is not required. Apocrine secretion involves apical protrusions and generates cytoplasmic fragments inside a secretory lumen. As we discovered, this process is accompanied by the release of large fragments of cellular structures and entire organelles that include mitochondria, Golgi, and portions of the endoplasmic reticulum (ER), among others (Farkaš et al. 2014), during its most intense phase. Proteomic analyses revealed that the secretion is composed of hundreds to thousands of microsomal, mitochondrial, ribosomal, membranous, cytoskeletal, and even nuclear as well as nucleolar proteins. Strikingly, although many nuclear proteins are released, the nuclear DNA itself remains intact (Farkaš et al. 2014). In spite of this complexity, it appears that several protein components of apocrine secretion are identical, regardless of the location of the apocrine gland (Farkaš 2015, 2016).

From a historical point of view, the first published study on an apocrine secretory organ was performed by Harder (1694) who described a special lachrymal gland in rodents. Some 140 years later, the human sweat gland, currently the most intensely studied apocrine organ, was discovered by Purkyně $(1833 \mathrm{a}, \mathrm{b})$ and described in detail by his pupil Wendt $(1833,1834)$. Almost simultaneously, their findings were confirmed and extended by Breschet and Roussel de Vouzeme (1834), and by Gurlt (1835). The axillary armpit glands, which contain the highest known concentration of apocrine sweat glands in the human skin, were first recognized by Horner (1846). Ranvier (1879) was the first author to distinguish "holocrine" secretion in the sebaceous gland from "eccrine/merocrine" secretion in the sweat glands. But it was not until 1922 when Schiefferdecker, based on Ranvier's observations, suggested that the secretory gland cells could be classified functionally according to how they secreted their contents, to an eccrine/merocrine, apocrine or holocrine mechanism. This made a breakthrough contribution as it established a clear functional definition of three substantially different categories of secretion based on the mechanism underlying the externalization of cellular materials.

Since that time, apocrine secretion has been confirmed and studied by many authors (Holmgren 1922, Herzenberg 1927, Mathis 1927, Moriyama 1927, Richter 1932, Richter and Schmidt, 1934, Kato, 1936, Kuno, 1938, Wolf, 1940, Minamitani, 1941a, b, c). It has also been described in other tissues including mammary (Loeb, 1932, Dabelow, 1957, Bargmann and Knoop, 1959, Bunting, 1984) and ceruminous glands (Kawabata and Kurosumi, 1976, Kurosumi and Kawabata, 1977, Testa-Riva and Puxeddu, 1980). Interestingly, when we discovered apocrine secretion in Drosophila (Farkaš et al. 2014), a popular and widely used genetic model organism, it allowed a seminal reappraisal of our understanding of apocrine secretion. The insights gained from molecular genetic analyses of their salivary glands has provided a glimmer of hope for elucidating the mechanistic aspects of this fundamental process (Farkaš 2015). In the course of these and following studies we uncovered that the developmental period of the salivary glands shortly prior to apocrine secretion is dominated by highly intense vacuolation due to abundant clathrinmediated endosomal trafficking. This trafficking is affiliated with the re-secretion of numerous endocytosed proteins that had been produced by distant tissues (Farkaš et al. 2015, 2018). Resecretory activity in the literature is recurrently associated with transcytosis, however, until now the releasing phase of transcytosis has been almost uniformly linked to exocytotic secretion (Hermo and Mello 1987, Kobayashi et al. 2002, Vergés et al. 2004, 2007, Vergés, 2016). This prompted us to reinvestigate the relationship between (endosomal) uptake of extracellular cargo and its re-release by two substantially different mechanisms: exocytosis or apocrine secretion.

As shown in Figure 1, in this context, transcytosis is most frequently used term to describe the process where vesicle-dependent endocytosis on one pole of the cell is employed to uptake a cargo, and vesicledependent exocytosis on the other pole of the cell is used to release it (Rodman et al. 1990, Frank et al. 2009, de Lange 2012, Preston et al. 2014, Ayloo and Gu 2019). By other words, transcytosis is a type of transcellular 


\section{Basal Apical}

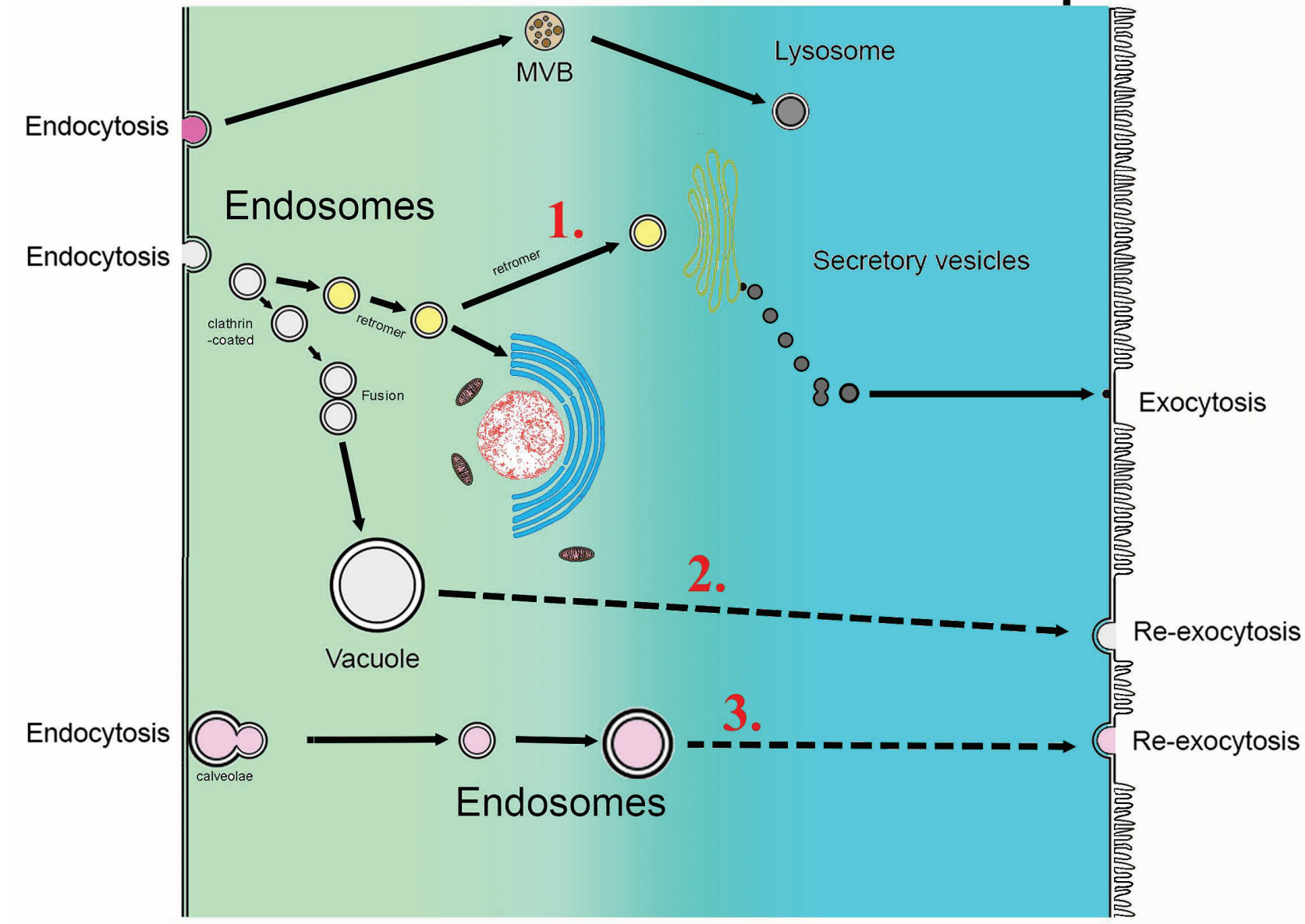

Fig. 1. Schematic illustration of transcytosis. In principle, endocytosis takes place on the basal or basolateral pole of the cell, endocytosed cargo captured in vesicles, which occasionally can fuse, is drawn across the cell, and ejected on the apical side of the cell by exocytosis. There is well-documented evidence that retromer (comprising of Vps26, Vps29, Vps35 and two sorting nexins e.g. SNX1/SNX2, SNX1/SNX5 or SNX5/SNX6) are chiefly involved in the mediation of this clathrin-dependent (gray vesicles) transport via the trans-Golgi network or ER system (yellow vesicles). This route strikingly differs from endosomal trafficking leading to multivesicular bodies (MVB) and lysosomes (brown and dark brown). However, ejection of the vesicles on the apical side can also involve clathrinindependent and caveolin-associated less circuitous route (pink vesicles) that is achieved by direct or close-to-direct movement between basal/basolateral and the apical domains, thus representing a simplified form of transcytosis. Under these circumstances, the cargo is re-exocytosed quickly and without any change. At the same time, the cell can produce its own, distinct secretory vesicles (dark violet) targeted for exocytosis. Large red numbers indicate the three main routes of transcytosis: 1 . and 2. utilise clathrin-dependent endocytosis, while 3. is caveole-linked and clathrin-independent. $\mathrm{L}=$ lumen.

passage in which various droplets, molecules, or particles are transported across the interior of a polarized cell (Apodaca et al. 1991, Antohe et al. 1997, Simionescu et al. 2002, Lodish et al. 2013, Alberts et al. 2015, Villaseñor et al. 2017). Cytopempsis appears to be a specific form of transcytosis of a substance into a cell (and through the cytoplasm in a micropinocytotic vesicle) followed by its release to the cell exterior without utilization by the cell (Staubesand 1965, Ma et al. 1974, Weiss 1979, Thorn et al. 1983, Platz 2006). As described in detail in this review, transcytosis is a complex endosomal process with numerous players and routes, and can serve both unidirectional and bidirectional transport with or without modification of a cargo. A significantly less abundant term used in association with transcellular traffic is transudation, the process of oozing or seeping when a substance is released along with some fluid. Transudation is usually connected to the release of sweat or the process of vascular exuding, the escape of liquids from blood vessels through pores or breaks in the cell membranes, and is caused by disturbances of hydrostatic or colloid osmotic pressure (Auerswald et al. 1952, Schorn et al. 1975, Predescu et al. 2007, Sun et al. 2009). In broader terms, transudation describes the passage of a fluid or solute through a membrane by hydrostatic or osmotic pressure. 
In medicine, it is often, but not exclusively, used to identify vascular leakage of vessels fluid that can cause cirrhosis-, nephrotic syndrome- or malnutritionassociated hypoalbuminism along with some other pathologies (Venkatarami and Govindappa 1985, Dubey et al. 2001, Vlachogiannakos et al. 2013, Bañares and Bernardi, 2019, Di Pascoli et al. 2019). In the present study we discuss several cases where transudation has been observed and is involved in the release of various serum components, colonic mucosa, ascitic fluid, pulmonary fluids, saliva, tears, ascitic fluid, cervicovaginal and oviductal secretions, etc., which share numerous common protein entities many of which are re-released but not produced by the tissue. A common feature of these tissue fluids is that they are released by apocrine secretion. Taking into consideration our recent clarification and re-definition of apocrine secretion as a non-canonical and non-vesicular transport and secretory mechanism (Farkaš 2015), we herein summarize the collective and prevailing attributes of transcytosis and transudation which may share only the uptake mechanism (endocytosis). Furthermore, we establish crucial differences on the discharge side, where emission of the cargo is mediated, via exocytosis vs. apocrine machinery, respectively.

\section{Basal Apical}

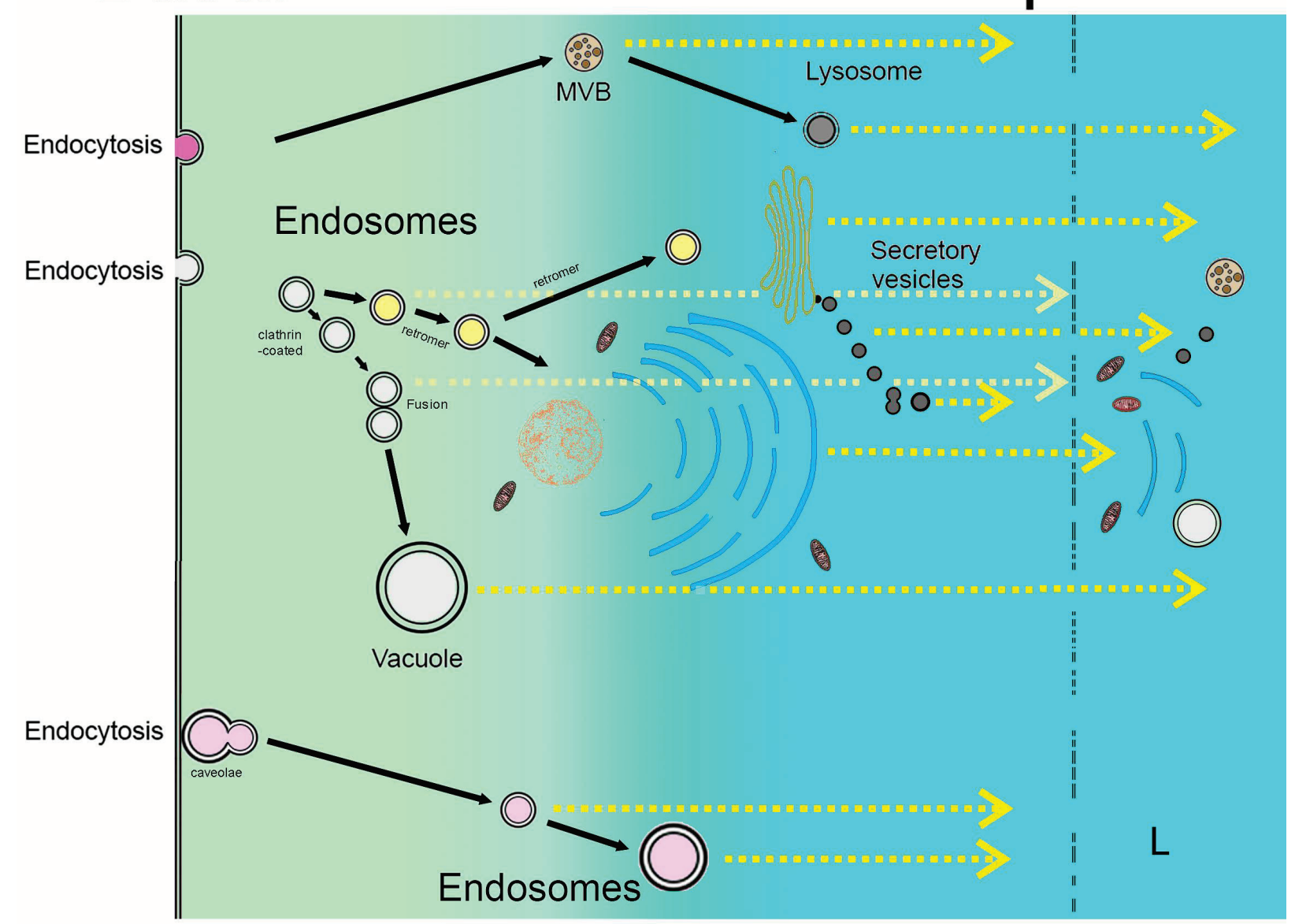

Fig. 2. Schematic illustration of transudation. Material endocytosed on the basal or basolateral pole of the cell, in a similar manner as during transcytosis, is released on the apical pole by apocrine secretion, allowing the massive externalization of many more proteins than were endocytosed, and often together with hundreds, if not thousands of the cell own products. In comparison to transcytosis, many more products are re-released than during transcytosis. The initial phases of the process (endocytosis) can utilize the same vesicular mechanisms for internalization on the basal and basolateral pole as during transcytosis, but the subsequent stages are directed towards massive apocrine secretion which is a completely non-vesicular pathway, many of its steps remain enigmatic at the molecular level. Nevertheless, experimental evidence suggests that numerous foreign proteins, produced by distal cells and tissues that are internalized from circulation by endocytosis, are detected among the plethora of products manufactured by the epithelial secretory cell which release them en masse via the apocrine mechanism which involves various cellular components including entire or parts of organelles such as ER, Golgi, mitochondria (orange), microsomes and even unsorted vesicles if they were present at the moment of secretion. $\mathrm{L}=$ lumen. 


\section{Transcytosis}

\section{Entrance phase - endocytosis and early sorting}

Transcytosis has been observed in connection with numerous transport and externalization processes of the cell. Several detailed studies of transcytosis-linked processes described in the literature are associated with engulfment or endocytosis and baso-apical recycling of the vacuolar ATPase proton pump (vATPase) required for luminal acidification of endosomes, characteristic for many transporting epithelia (Brown and Sabolić, 1993, Brown and Breton, 2000). Although under various circumstances transport from the basal and basolateral pole to the apical pole or vice versa does not fulfill the features of complete transcytosis, it does represent the bipolar transcellular transport of membrane constituents (Schneider et al. 1979, de Chastellier et al. 1987), therefore we still can learn important information from these studies. In experiments with artificial cargo such as native ferritin (NF) or horseradish peroxidase (HRP) to trace fluid-phase endocytosis, or with cationized ferritin (CF) to examine adsorptive endocytosis, it is possible to follow clathrin-mediated endocytosis when tracers first enter an apical tubulovesicular endosomal system, then larger apical endosomal vesicles and later multivesicular bodies (MVB).

It is widely accepted that the intracellular network of endosomes is a highly organized cluster of membrane-derived compartments that act as sorting sites for both, endosomal and biosynthetic cargo. The subsequent fate of the engulfed cargo depends upon its interaction with a variety of molecularly distinct processing complexes, which tightly regulate the close relationship between the sorting of their particular load and the native process of membrane re-carving, essential for the proper formation of transport carriers (McGough and Cullen 2011, Shen et al. 2018). One such complex, retromer, among others primarily mediates retrograde transport from endosomes to the trans-Golgi network (TGN) (Burd and Cullen 2014, Gallon and Cullen 2015, Abubakar et al. 2017, Kvainickas et al. 2017, Simonetti et al. 2017). Nonetheless, the bipolar transport of membrane components, such as vATPase, must be able to escape these degradative routes. Even though this membrane component is not necessarily produced by other distal tissues (and therefore not has undergone adsorptive endocytosis), it is still able to enter the same efficient intracellular transport and delivery mechanism as foreign cargo, which is either identical or similar to the transcytotic route.

Kumagai et al. (2011) described the binding of IgG to the neonatal Fc receptor (FcRn) followed by internalization of this complex, and suggested apical receptor-mediated transcytosis via the TGN. Subsequently, the FcRn located inside the apical plasma membrane binds maternal $\mathrm{IgG}$, and becomes internalized by endocytosis into the absorptive cells. The FcRn plays a key role in providing the fetus or newborn with humoral immunity before its immune system becomes fully developed as it transports maternal IgG across various epithelial barriers. The authors concluded that in newborns, FcRn transfers IgG from milk to blood by apical-to-basolateral transcytosis across intestinal epithelial cells. The work of He et al. (2008) showed that the efficient unidirectional transport of $\operatorname{IgG}$ within the intestinal epithelial cells is facilitated by a $\mathrm{pH}$ difference between the apical ( $\mathrm{pH}$ 6.0-6.5) and basolateral ( $\mathrm{pH} 7.4$ ) sides, since FcRn binds IgG at $\mathrm{pH}$ 6.0-6.5 but not at $\mathrm{pH} 7$ or more, the basolateral $\mathrm{pH} 7.4$ facilitates release of the cargo. The maternal IgG is absorbed by FcRn-expressing cells in the proximal portion of the small intestine (the duodenum and jejunum) when milk passes through the neonatal digestion, the remaining proteins are absorbed or degraded by FcRn-negative cells in the distal portion of the small intestine (ileum). In this context, a more complex view in which Fc moves throughout networks of entangled tubular and irregular vesicles before it reaches the basolateral surface was investigated by a combination of electron tomography and non-perturbing endocytic labeling (He et al. 2008). Distinct markers for early, late and recycling endosomes, each labeling vesicles in different and overlapping morphological classes, have helped these authors to reveal the spatial complexity in endolysosomal trafficking. These observations elucidated important features of transcytosis, including transport involving multivesicular bodies, inner vesicles/tubules and exocytosis through clathrin-coated pits. They also indicate that MVBs, most likelly a specific subclass of them, are involved in processive transcytosis and act in a distinct non-lysosomal (non-degradative) pathway, possibly requiring a specific sorting mechanism.

\section{Post-entrance phase - the central role of retromer}

The endosomal system is composed of an interconnected network of diverse membrane-bound structures and subcellular compartments whose primary function is to receive, dissociate, and sort cargo that originates either at the plasma membrane or from 
biosynthetic pathways (McGough and Cullen 2011, Burd and Cullen 2014, Gallon and Cullen 2015). Several years ago, there was a large amount of interest in a system associated with transcytosis after endosomal uptake and trafficking of polymeric immunoglobulin receptor (pIgR) and the role of a retromer complex in this process (Kobayashi et al. 2002, Vergés et al. 2004, 2007). Retromer consists of two major components: (1) a heterotrimer encoded by the vacuolar protein sorting (Vps) genes Vps26, Vps29, and Vps35, the role of which is to select cargo, and (2) a dimer of phosphoinositidebinding sorting nexins (SNX), whose function is to deform the membrane (Bonifacino and Hurley 2008, Vergés 2016). In other words, retromer is a heteropentameric complex that associates with the cytosolic face of vesicles and mediates the retrograde transport of transmembrane cargo from endosomes to the TGN. It comprises a sorting nexin dimer composed of a combination of SNX1, SNX2, SNX5, or SNX6, and a cargo-recognition trimer containing Vps26, Vps29 and Vps35. The SNX subunits contribute by Bin/Amphiphysin/Rvs (BAR) and phosphoinositidebinding phox homology (PX) domains that allow binding to the $\mathrm{PI}_{3} \mathrm{P}$-enriched highly curved membranes of endosomal vesicles, whereas Vps26, Vps29 and Vps35 subunits functionally contribute by phosphoesterase, arrestin and $\alpha$-solenoid folds, respectively (Bujny et al. 2007, Bonifacino and Hurley 2008, van Weering et al. 2010, Vergés 2008, 2016).

Following endocytosis, pIgR is trafficked from the basal to the apical membrane. This trafficking pathway may be attenuated by the suppression of Vps35, a key constituent of retromer (McGough et al. 2014). Similarly, cells expressing some pIgR mutations defective in trafficking can have their transcytosis phenotype rescued by the overexpression of wild-type Vps35. In a study using endosomal fractions prepared from liver, pIgR antibody co-immunoprecipitated Vps26, Vps29 and Vps35, showing the close interactions and overall biochemical relationship between the trimer components of retromer and pIgR (Vergés et al. 2004). Although only negligible amounts of sorting nexin SNX1 and SNX2 were pulled down in these experiments, it still remains possible that sorting nexins are also required for this process, as the rescue by $\mathrm{Vps} 35$ is $\mathrm{PI}_{3} \mathrm{P}$ sensitive (Vergés et al. 2007). In connection with the above mentionedd MVBs capable of avoiding the degradative route, these findings suggest that retromer complex may play a central or crucial role in escaping $\mathrm{pIgR}$, and potentially other cargoes, from the lysosomal pathway and directing it for transcytosis.

\section{Game of multiple traffick and its fine tuning}

Retromer is known as a critical regulator of multiple export and sorting pathways from endosomes. Other cargo proteins that rely on retromer for trafficking also exist, including Drosophila crumbs, a protein essential for maintaining apico-basolateral polarity (Pocha et al. 2011, Zhou et al. 2011), serpentine, a protein required for tracheal development in Drosophila (Dong et al. 2013) and auxin efflux carriers in plants (Kleine-Vehn et al. 2008). Originally, Vps35 was identified in a screen for genes that function in endocytosis in the D. melanogaster Schneider 2 cultured cell line (Korolchuk et al. 2007), and further characterized as a protein required for the endocytosis of mBSA, the scavenger receptor Croquemort, EGF receptor and various other proteins, but not for synaptic vesicle endocytosis. These and other authors speculate that the endocytosis defect is a result of the regulation of Rac by Vps35, by an undefined mechanism (Korolchuk et al. 2007, Dong et al. 2013). The proposed theory is based upon a genetic interaction between Rac and Vps35, as well as the increased levels of F-actin present in the Vps35 mutant background. As such, it is logical to assume that the list of proteins that are known to be carried by retromer will grow significantly. However, the specific mechanism that distinguishes whether a particular cargo should avoid the endo-lysosomal pathway and instead undergo transcyctosis remains to be elucidated.

When considering pIgR, one working hypothesis is that the retromer could function by directly promoting pIgR transcytosis by rescuing the receptorligand complex from the degradative pathway (Vergés et al. 2004, 2007). To test this hypothesis, the region of the pIgR cytoplasmic domain that interacts with Vps35 was mapped. Interaction between the cytoplasmic domain of pIgR and Vps35 is necessary for retromer to promote transcytosis. However, such an interaction is not necessary to avoid cargo degradation, as very little pIgA internalized by $\mathrm{pIgR}-725 \mathrm{t}$ is degraded, with or without altering Vps35 levels (Luton et al. 1998), suggesting that retromer does not function primarily by rescuing $\mathrm{pIgR}$ from degradation. At present, transcytosis and degradation are considered to be alternative pathways, and thus anything that directly affects one is likely to indirectly affect the other (Breitfeld et al. 1990, Vergés 
et al. 2004, 2007, Vergés 2008, 2016). Because of this tight connection, it is difficult to completely exclude a function for retromer in avoidance of, or retrieval from, the degradative pathway. However, a plausible mechanistic explanation may involve consideration of additional, but thus far unidentified players. This could be, for example, additional interacting partner(s) or a posttranslational modification of a retromer subunit or endosomal cargo vesicle component.

\section{Retromer and sorting in concert}

Biochemical and immunohistochemical studies have revealed the subcellular localization of retromer and retromer subunits in the post-endocytic pathway. Although subunits of the cargo-selective complex were enriched in early endosomes (EEs), levels of SNX2 were greater in sorting endosomes. An estimated $25 \%$ of total Vps26 and SNX2 was localized in EEs, with negligible portions in recycling endosomes as well as in late endosomes and lysosomes. Although Vps26 was found in structures of more heterogeneous size and shape than SNX2, these markedly overlapped. As a consequence, the two retromer subcomplexes mostly colocalized. Remarkably, retromer was found preferentially as part of the transcytotic pathway. Other studies have shown that pharmacological inhibition of phosphoinositide 3-kinase affected the co-distribution of retromer with $\mathrm{pIgA}$ and the cation-independent mannose 6-phosphate receptor (CI-MPR), delaying pIgA progress to the apical surface (Mellado et al. 2014, Vergés 2016, Kvainickas et al. 2017).

Retromer as an evolutionarily conserved protein complex required for endosome-to-Golgi transport is necessary also for the retrieval of lysosomal hydrolases receptors (McGough and Cullen 2011, Gallon and Cullen 2015, Abubakar et al. 2017). A dimer of two sorting nexins, typically $\mathrm{SNX} 1 / \mathrm{SNX} 2$ or $\mathrm{SNX} 1 / \mathrm{SNX} 5$ or SNX1/SNX6, deforms the membrane and thus cooperates with retromer to ensure cargo sorting. Wassmer et al. (2009) established that retromer activity depends on a dynamic spatial organization of the endosomal network regulated via the association of SNX5/SNX6 with the "glued" p150 component of dynactin, which serves as an activator of the minus-end directed microtubule motor dynein. The spatial organization of the retromer activity is directed through the association of SNX1 with the proposed TGN-localized Rab6-interacting protein-1 (RIP-1). The stepwise sequence of these interactions is fundamental for retromer-mediated transport and strongly suggests that a critical element required for efficient retromer-mediated sorting is defined by the spatial organization of the retromer network. The role of retromer as well as SNXs in endosomal protein (re)cycling and protein targeting to specialized plasma membrane domains in polarized cells, including transcytosis, adds further complexity and has implications in growth control, the establishment of developmental patterns, cell adhesion, migration, etc.

However, it needs to be stressed here that some proteins may be targeted to their ultimate destination immediately after endocytosis via a less circuitous route that can involve direct movement between the basal/basolateral and apical domains (Kobayashi et al. 2002, Rojas and Apodaca 2002, Hoessli et al. 2004, Fuchs and Ellinger 2004). This type of simplified transcytosis is considered to be clathrin-independent uptake which occurs via caveolae or other membrane microdomains. Caveolae are small flask-shaped plasma membrane invaginations that contain the protein caveolin-1. They are relatively static structures, but a number of factors can stimulate caveolae uptake, creating caveosomes (Parton et al. 1994, Pelkmans and Helenius 2002, Thomsen et al. 2002, Mukherjee et al. 2006). The uptake of caveosomes is likely to be similar to clathrin-mediated endocytosis because caveolae are enriched in proteins that function in membrane docking and fusion events (Schnitzer et al. 1995, Oh et al. 1998). Caveolae may be a subgroup in a broader class of membrane microdomains that are involved in facilitating endocytic events (Johannes and Lamaze 2002, Laude and Prior 2004, Alfalah et al. 2005, Stan 2005, Cheng et al. 2006).

\section{Transudation}

\section{A link between transudation and apocrine}

Historically, the transudation process has mainly been associated with the exudation of various serum components (e.g. immunoglobulins, albumins, numerous enzymes) into mucous body fluids including nasal mucus, saliva, tears, ascitic fluid, pulmonary fluids, etc. and often shown to be exacerbated during injury and inflammation (Auerswald et al. 1952, Schorn et al. 1975, Malmendier and Amerijckx 1976, Selinger et al. 1979, Gachon et al. 1982, Janssen and van Bijsterveld 1983, Kuhn et al. 1983, Bard et al. 2002, Bours et al. 2005). In addition to these body fluids, the process has also been observed in association with cervical fluid 
(or cervicovaginal secretions) (Schumacher 1970, Schwarz et al. 2010, Petäjä et al. 2011), middle ear fluid (MEF) or cerumen (Ishikawa et al. 1972, Howie et al. 1973, Jones et al. 1979, Bernstein 2002, Kaur et al. 2012), bronchoalveolar fluid (Osebold et al. 1975), seminal plasma (Tauber et al. 1975, Lizana et al. 1987), colonic mucosa (Prigent-Delecourt et al. 1995), sputum (Vogel et al. 1997), corporeal fluid (Bélec 2002), oviductal secretions (Buhi et al. 2000), and peritoneal fluid (as a result of endosalpingeal secretion) (Hunter et al. 2007).

In the great majority of cases the common feature of these transudates or exudates is the presence of the same or closely related proteins such as serum albumin, immunoglobulins (IgG1, IgG2, IgA, and IgM), lactoferrin, transferrin, alpha 1-antitrypsin (AAT), lysozyme, C'3-component of complement, ceruloplasmin, fibrinogen, eosinophil cationic protein (ECP), tumor necrosis factor $\alpha$ (TNF- $\alpha$ ), transforming growth factor (TGF)-beta1 (TGF- $\beta 1$ ), alpha 2-macroglobulin. Consequently, some of these proteins e.g. serum albumin, secretory immunoglobulin A (S-IgA), AAT, lysozyme, lactoferrin and transferrin were then frequently used as transudation markers (Dufour et al. 2005). The mucosal regions of the body, where these proteins are secreted, are responsible for defense against environmental pathogens. Particularly in the lumen of the vas deferens, intestinal and colonic lumens, airway lumen, oviductal and vaginal lumen the antibodyand defense proteins-mediated immune responses are critical for preventing invasion by pathogens (Gonnella and Neutra 1984, Hermo and de Melo, 1987, Oshikawa et al. 1996, Parr et al. 1998, Buhi et al. 2000, Hermo et al. 2000, MacPherson and Uhr 2004, Hamburger et al. 2006). Interestingly, all of the listed proteins are also markers of apocrine secretion, as previously compiled and defined (Farkaš 2015). This list of apocrine markers is now longer and continuously growing, however, there is no doubt that all listed tissues or organs displaying the capability of transudation are also polarized epithelia using apocrine secretion to deliver intracellular proteins to mucosal regions of the body where they serve as a barrier at the exterior interface.

\section{Apocrine mechanism}

The definition of apocrine secretion as a noncanonical and non-vesicular transport and secretory mechanism was possible due to its serendipitous discovery in prepupal salivary glands of Drosophila
(Farkaš et al. 2014). This genetically well defined model organism provided us with an exceptional opportunity to elucidate the mechanistic aspects of this fundamental process through molecular, cellular, and developmental analyses. It was also a chance to undertake a critical reappraisal and comprehensive review of our knowledge on apocrine secretion in order to place new findings in a historical context and, at the same time, develop new concepts that encapsulate the basic features of apocrine secretion using insights from the most recent data. In addition to the already established phrases and definitions which have been used in the description of apocrine secretion for almost a century, the most intense phase of apocrine extrusion in the Drosophila salivary gland is accompanied by the release of large cellular fragments including entire organelles or their structurally compact nondisintegrated parts: mitochondria, microsomes, Golgi zone and areas of the ER (Farkaš et al. 2014, Farkaš 2015). Thus, apocrine secretion is composed of membranous, cytoskeletal, microsomal, mitochondrial, ribosomal, and most surprisingly, nuclear and even nucleolar proteins. Apocrine secretion is characterized by massive protein release, rather than being solely devoted to the secretion of oily substances, as was previously incorrectly defined (Purkyně 1833b, Schiefferdecker 1917, 1921, Richter 1932, Kuno 1938, Hurley and Shelley 1954, Gesase et al. 1996, Gesase and Satoh 2003).

Preliminary and current proteomic analyses of the apocrine secretory material have revealed that it is a highly complex mixture consisting of hundreds to thousands of proteins from different subcellular locations and with highly diverse functions. These proteins include enzymes, structural proteins, signaling molecules, membrane and intracellular receptors, chaperones, storage proteins, transcription factors, coactivators and corepressors, chromatin and nucleolar components (Farkaš 2015, 2016). Although numerous nuclear proteins are released, nuclear DNA and nuclei appear completely intact (Farkaš et al. 2014). By isolating freshly secreted material directly from the lumen of the Drosophila salivary glands and evaluating the presence of specific proteins using a broad panel of antibodies in western blotting, we demonstrated that proteins are released undegraded, and most probably fully functional (Farkaš et al. 2014). Even though many of the proteins that we analyzed are actively released to undetectable levels inside cells, they start to slowly reappear at their original subcellular locations within about an hour after the 
completion of apocrine secretion. In addition, the tissue, even though it has undergone massive apocrine secretion, continues to live and produce gene products as shown by the incorporation of radioactive precursors into newly transcribed RNA and newly synthesized proteins. When the fluorescent signal from secondary antibodies or GFP/RFP-/YFP- fusion proteins that were released into the lumen was quantified, more than $90-95 \%$ of these proteins were found to be secreted from the cells, suggesting that the remaining few percent of a cell's proteome is sufficient to maintain tissue viability and allow for its rapid regenration (Farkaš et al. 2014).

\section{Heavy endosomal traffick, vacuolation and resecretion in an apocrine organ}

Equally unanticipated as apocrine secretion was the finding that Drosophila salivary glands during the early prepupal period are remarkably active in endocytosis, generating high numbers of small acidic vacuoles that continuously fuse to larger ones. Midway through the prepupal period, there is an abundance of late endosomal trafficking and vacuole growth, later followed by vacuole neutralization and disappearance via membrane consolidation (Farkaš et al. 2015). All this endosomal activity, in which a crucial role is played by dynamin, clathrin, Rab5, Rab11, syntaxins, vacuolar ATPases Vha36-1, Vha55, Vha68-2, etc., takes place a few hours prior to apocrine secretion. The final phases of this process, involving vacuole disappearance and their fusion with membranes of ER and TGN, are controlled by Drosophila retromer constituent, Vps35 (Farkaš et al. 2015). It has been determined that among apocrine secretory products which are released by salivary glands there are several proteins which are not produced by themselves, but must be taken up from the surrounding hemolymph by endocytosis (Farkaš et al. 2014).

It should be emphasized that apocrine secretion is characterized by massive protein release, which is in striking contrast to exocytosis when only a single product or a few proteins are released from vesicles, homotypically fusing with the cell membrane. Thus, in the majority if not all above mentioned cases, when immunoglobulins, albumins, various enzymes, lactoferrin, transferrin, AAT, lysozyme, alpha 2-macroglobulin, ceruloplasmin, fibrinogen, ECP, $\mathrm{C}$ '3-component of complement, TNF- $\alpha$, and many others that are not synthesized by a secretory organ, are released into exocrine mucous regions and body fluids of mammals, apocrine secretion is involved. All these data suggest that early endocytosis as well as further cargo sorting and selection for the post-endocytic pathway using retromer (Vergés et al. 2004, 2007, Vergés, 2008, 2016, Bonifacino and Hurley 2008, Kleine-Vehn and Friml 2008, van Weering et al. 2010, Burd and Cullen 2014, Gallon and Cullen 2015) might be common to both the re-release of engulfed proteins by exocytosis (transcytosis) and apocrine secretion (transudation). However, at present we cannot conclude which of the retromer subcomplexes are preferentially used in transcytosis and which are used in transudation, or whether they are distinct at all.

Retromer or its vicinity - potenial intersection point for transcytosis and transudation

Due to the non-vesicular character of apocrine transport and the secretory mechanism, differences at the post-endocytic pathway and later stages at the level of cargo recognition, sorting and/or selection will exist which will allow bulky recruitment of the specified cargo to this massive externalization pathway. This conclusion opens up new vistas for investigation in the future. There is no exocytosis during or after apocrine secretion in Drosophila salivary glands (Farkaš et al. 2014, 2016) and thus proteins taken up from circulation via endocytosis during the early prepupal stages can be released or secreted only by the apocrine pathway. The involvement of retromer in this preceding endocytosis has been already evidenced (Farkaš et al. 2015). This finding poses an important question: in the case of apocrine secretion, does any preceding endocytosis for the purpose of re-secretion, require clathrin-dependent retromerassociated sorting machinery and automatically exclude caveolae-mediated endocytosis?

Transcytosis may be either unidirectional or bidirectional. Unidirectional transcytosis may occur selectively in the luminal to abluminal direction, or in the reverse direction (abluminal to luminal). However, apocrine secretion occurs exclusively on the apical pole and therefore this type of transport and re-secretion is only unidirectional providing grounds to consider these as two separate mechanisms, another reason to clearly differentiate transudation from trancytosis (see Figs 1 and 2). This differentiation opens up several new and interesting avenues of enquiry, such as the existence of crosstalk or the interconnection between an endosomal (vesicular) system and apocrine secretion which in principle is a non-vesicular mechanism, or in other words, how endocytosed material of foreign origin 
becomes integrated into apocrine machinery or whether this endocytosed material needs a specific sorting mechanism to escape the vesicular pathway on the route to being released. The above described system of Drosophila salivary glands can easily be used to explore these and similar questions by designing biochemical protein-protein interaction studies or screens for genetic interactions focused directly on key trafficking components and the apocrine machinery itself.

\section{Conflict of Interest}

There is no conflict of interest.

\section{Acknowledgements}

The research on apocrine secretion was, in part, supported by VEGA 2/0103/17, by COST ENBACA15216 grant, EEA-Norwegian FM SK-0086 grant, and APVV-16-0219 grant to R.F., and in part by the grants from the Czech Science Foundation: GACR P302/12/G157 (to I.R.) and GACR 19-19779S (to I.R), and by the projects from the Charles University: Progres Q28 (to I.R.), and Progres Q37 (to O.R.).

\section{Abbreviations}

AAT $=$ alpha 1-antitrypsin

$\mathrm{BAR}=\mathrm{Bin} /$ Amphiphysin $/$ Rvs

$\mathrm{BSA}=$ bovine serum albumin

$\mathrm{CF}=$ cationized ferritin

CI-MPR = cation-independent mannose 6-phosphate receptor
$\mathrm{ECP}=$ eosinophil cationic protein

$\mathrm{EE}=$ early endosome

$\mathrm{EGF}=$ epidermal growth factor

$\mathrm{EGFR}=\mathrm{EGF}$ receptor

$\mathrm{ER}=$ endoplasmic reticulum

$\mathrm{Fc}=$ fragment crystallizable

$\mathrm{FcRn}=$ neonatal $\mathrm{Fc}$ receptor

$\mathrm{GFP}=$ green fluorescent protein

$\mathrm{HRP}=$ horseradish peroxidase

Ig = immunoglobulin

$\mathrm{MEF}=$ middle ear fluid

$\mathrm{MVB}=$ multivesicular bodies

$\mathrm{NF}=$ native ferritin

$\mathrm{PI}_{3} \mathrm{P}=$ phosphoinositide phosphate

$\mathrm{pIgA}=$ polymeric immunoglobulin $\mathrm{A}$

$\mathrm{pIgR}=$ polymeric immunoglobulin receptor

$\mathrm{PX}=$ phox homology

$\mathrm{Rab}=$ Ras-related proteins in brain

Rac $=$ Ras-related C3 botulinum toxin substrate

Ras $=$ Rat sarcoma

$\mathrm{RFP}=$ red fluorescent protein

RIP-1 = Rab6-interacting protein-1

SNX $=$ sorting nexins

TGF- $\beta 1=$ transforming growth factor-beta 1

$\mathrm{TGN}=$ trans - Golgi network

TNF- $\alpha=$ tumor necrosis factor $\alpha$

vATPase $=$ vacuolar ATPase proton pump

VPS $=$ vacuolar protein sorting

YFP $=$ yellow fluorescent protein

\section{References}

ABUBAKAR YS, ZHENG W, OLSSON S, ZHOU J: Updated Insight into the Physiological and Pathological Roles of the Retromer Complex. Int J Mol Sci 18: E1601, 2017. https://doi.org/10.3390/ijms18081601

ALBERTS B, JOHNSON A, LEWIS J, RAFI M, ROBERTS K, WALTER P: Molecular Biology of the Cell 6th edition. Garland Science, Taylor and Francis Group, New York, Abingdon, 2015.

ALFALAH M, WETZEL G, FISCHER I, BUSCHE R, STERCHI EE, ZIMMER K, SALLMANN HP, NAIM HY: A novel type of detergent-resistant membranes may contribute to an early protein sorting event in epithelial cells. J Biol Chem 280: 42636-42643, 2005. https://doi.org/10.1074/jbc.M505924200

ANANTHARAM A, KREUTZBERGER AJB: Unraveling the mechanisms of calcium-dependent secretion. J Gen Physiol 151: 417-434, 2019. https://doi.org/10.1085/jgp.201812298

ANANTHARAM A, ONOA B, EDWARDS RH, HOLZ RW, AXELROD D: Localized topological changes of the plasma membrane upon exocytosis visualized by polarized TIRFM. J Cell Biol 188: 415-428, 2010. https://doi.org/10.1083/jcb.200908010

ANTOHE F, SERBAN G, RADULESCU L, SIMIONESCU M: Transcytosis of albumin in endothelial cells is brefeldin A-independent. Endothelium 5: 125-136, 1997. https://doi.org/10.3109/10623329709079871

APODACA G, BOMSEL M, ARDEN J: The polymeric immunoglobulin receptor. A model protein to study transcytosis. J Clin Invest 87: 1877-1882, 1991. https://doi.org/10.1172/JCI115211 
AUERSWALD W, BRAUNSTEINER H, WENZL M: Electrophoretic investigations on the mechanism of transsudation caused by congestion. Wien Z Inn Med 33: 164-165, 1952. https://doi.org/10.1177/104438945203300408

AYLOO S, GU C: Transcytosis at the blood-brain barrier. Curr Opin Neurobiol 57: 32-38, 2019. https://doi.org/10.1016/j.conb.2018.12.014

BAÑARES R, BERNARDI M: Long-term albumin administration in patients with decompensated cirrhosis. It is time for a reappraisal. Liver International 39: 45-48, 2019. https://doi.org/10.1111/liv.13996

BARCLAY JW, MORGAN A, BURGOYNE RD: Calcium-dependent regulation of exocytosis. Cell Calcium 38: 343-353, 2005. https://doi.org/10.1016/j.ceca.2005.06.012

BARD E, LAIBE S, CLAIR S, BIICHLÉ S, MILLON L, DROBACHEFF C, BETTINGER D, SEILLÈS E, MEILLET D: Nonspecific secretory immunity in HIV-infected patients with oral candidiasis. J Acquir Immune Defic Syndr 31: 276-284, 2002. https://doi.org/10.1097/00126334-200211010-00002

BARGMANN W, KNOOP A: Über die Morphologie der Milchsekretion. Licht- und elektronenmikroskopische studien an der Milchdrüse der Ratte. Z Zellforsch 49: 344-388, 1959. https://doi.org/10.1007/BF00334733

BECK R, RAVET M, WIELAND FT, CASSEL D: The COPI system: Molecular mechanisms and function. FEBS Lett 583: 2701-2709, 2009. https://doi.org/10.1016/j.febslet.2009.07.032

BÉLEC L: Defenses of the female genital tract against infection. J Gynecol Obstet Biol Reprod (Paris) 31 (6 Suppl): 4S45-4S59, 2002.

BERNSTEIN JM: Immunologic aspects of otitis media. Curr Allergy Asthma Rep 2: 309-315, 2002. https://doi.org/10.1007/s11882-002-0056-4

BONIFACINO JS, HURLEY JH: Retromer. Curr Opin Cell Biol 20: 427-436, 2008. https://doi.org/10.1016/j.ceb.2008.03.009

BOURS J, REITZ C, STROBEL J, BREIPOHL W: Detection of secretory IgM in tears during rhino-conjunctivitis. Graefes Arch Clin Exp Ophthalmol 243: 456-463, 2005. https://doi.org/10.1007/s00417-004-1048-y

BREITFELD PP, CASANOVA JE, MCKINNON WC, MOSTOV KE: Deletions in the cytoplasmic domain of the polymeric immunoglobulin receptor differentially affect endocytotic rate and postendocytotic traffic. J Biol Chem 265: 13750-13757, 1990.

BRESCHET G, DE VAUZEME R: Recherches anatomiques et physiologiques sur les appareils tegumentaires des animaux. Ann des Sci Nat, 2e ser., Zool. II: 167-238, 321-370, 1834.

BROWN D, BRETON S: H+V-ATPase-dependent luminal acidification in the kidney collecting duct and the epididymis/vas deferens: vesicle recycling and transcytotic pathways. J Exp Biol 203: 137-145, 2000.

BROWN D, SABOLIĆ I: Endosomal pathways for water channel and proton pump recycling in kidney epithelial cells. J Cell Sci Suppl 17: 49-59, 1993. https://doi.org/10.1242/jcs.1993.Supplement_17.8

BUHI WC, ALVAREZ IM, KOUBA AJ: Secreted proteins of the oviduct. Cells Tissues Organs 166: 165-179, 2000. https://doi.org/10.1159/000016731

BUJNY MV, POPOFF V, JOHANNES L, CULLEN PJ: The retromer component sorting nexin-1 is required for efficient retrograde transport of Shiga toxin from early endosome to the trans Golgi network. J Cell Sci 120 : 2010-2021, 2007. https://doi.org/10.1242/jcs.003111

BUNTING H: Cytochemical properties of apocrine sweat glands normally present in the human mammary gland. Anat Rec 101: 5-12, 1984. https://doi.org/10.1002/ar.1091010103

BURD C, CULLEN PJ: Retromer: a master conductor of endosome sorting. Cold Spring Harb Perspect Biol 6: a016774, 2014. https://doi.org/10.1101/cshperspect.a016774

CHENG Z, SINGH RD, MARKS DL, PAGANO RE: Membrane microdomains, caveolae, and caveolar endocytosis of sphingolipids. Mol Membr Biol 23: 101-110, 2006. https://doi.org/10.1080/09687860500460041

CHIEREGATTI E, MELDOLESI J: Regulated exocytosis: new organelles for non-secretory purposes. Nat Rev Mol Cell Biol 6 181-187, 2005. https://doi.org/10.1038/nrm1572

COUSIN MA: Integration of synaptic vesicle cargo retrieval with endocytosis at central nerve terminals. Front Cell Neurosci 11: 234, 2017. https://doi.org/10.3389/fncel.2017.00234 
DABELOW A: Die Milchdrüse. In: Handbuch der mikroskopischen Anatomie des Menschen. Dritter Band, Haut und Sinnesorgane. Dritter Teil, die Haut die Milchdrüse. W VON MÖLLENDORFF, W BARGMANN (eds), Springer Verlag, Berlin, 1957, pp 277-485. https://doi.org/10.1007/978-3-642-47921-2_2

DEAK F, XU Y, CHANG WP, DULUBOVA I, KHVOTCHEV M, LIU X, SÜDHOF TC, RIZO J: Munc18-1 binding to the neuronal SNARE complex controls synaptic vesicle priming. J Cell Biol 184: 751-764, 2008. https://doi.org/10.1083/jcb.200812026

DE CHASTELLIER C, LANG T, RYTER A, THILO L: Exchange kinetics and composition of endocytic membranes in terms of plasma membrane constituents: a morphometric study in macrophages. Eur J Cell Biol 44: 112-123, 1987.

DE LANGE EC: The physiological characteristics and transcytosis mechanisms of the blood-brain barrier (BBB). Curr Pharm Biotechnol 13: 2319-2327, 2012. https://doi.org/10.2174/138920112803341860

DI PASCOLI M, FASOLATO S, PIANO S, BOLOGNESI M, ANGELI P: Long-term administration of human albumin improves survival in patients with cirrhosis and refractory ascites. Liver International 39: 98-105, 2019. https://doi.org/10.1111/liv.13968

DONG B, KAKIHARA K, OTANI T, WADA H, HAYASHI S: Rab9 and retromer regulate retrograde trafficking of luminal protein required for epithelial tube length control. Nature Commun 4: 1358, 2013. https://doi.org/10.1038/ncomms2347

DUBEY PK, SINHA PK, RAGHWENDRA KH: Anesthetic considerations in a patient with visceral leishmaniasis. Can J Anaesth 48: 529-531, 2001. https://doi.org/10.1007/BF03016827

DUFOUR V, MILLON L, FAUCHER JF, BARD E, ROBINET E, PIARROUX R, VUITTON DA, MEILLET D: Effects of a short-course of amoxicillin/clavulanic acid on systemic and mucosal immunity in healthy adult humans. Int Immunopharmacol 5: 917-928, 2005. https://doi.org/10.1016/j.intimp.2005.01.007

FARKAŠ R: Apocrine secretion: New insights into an old phenomenon. Biochim Biophys Acta 1850: 1740-1750, 2015. https://doi.org/10.1016/j.bbagen.2015.05.003

FARKA ̌ R: The complex secretions of the salivary glands of Drosophila melanogaster, a model system. In: Extracellular composite matrices in Arthropods. E COHEN, B MOUSSIAN (eds.), Springer International Publishing, Switzerland, 2016, pp 557-599. https://doi.org/10.1007/978-3-319-40740-1_15

FARKAŠ R, BEŇOVÁ-LISZEKOVÁ D, MENTELOVÁ L, BEŇO M, BABIŠOVÁ K, TRUSINOVÁ-PEČEŇOVÁ L, RAŠKA O, CHASE BA, RAŠKA I: Endosomal vacuoles of the prepupal salivary glands of Drosophila play an essential role in the metabolic reallocation of iron. Dev Growth Differ 60: 411-430, 2018. https://doi.org/10.1111/dgd.12562

FARKAŠ R, BEŇOVÁ-LISZEKOVÁ D, MENTELOVÁ L, MAHMOOD S, ĎATKOVÁ Z, BEŇO M, PEČEŇOVÁ L, RAŠKA O, ŠMIGOVÁ J, CHASE BA, RAŠKA I, MECHLER BM: Vacuole dynamics in the salivary glands of Drosophila melanogaster during prepupal development. Dev Growth Differ 57: 74-96, 2015. https://doi.org/10.1111/dgd.12193

FARKAŠ R, ĎATKOVÁ Z, MENTELOVÁ L, LÖW P, BEŇOVÁ-LISZEKOVÁ D, BEŇO M, SASS M, ŘEHULKA P, ŘEHULKOVÁ H, RAŠKA O, ŠMIGOVÁ J, RAŠKA I, MECHLER BM: Apocrine secretion in Drosophila salivary glands: subcellular origin, dynamics, and identification of secretory proteins. PLoS One 9: e94383, 2014. https://doi.org/10.1371/journal.pone.0094383

FRANK PG, PAVLIDES S, LISANTI MP: Caveolae and transcytosis in endothelial cells: role in atherosclerosis. Cell Tissue Res 335: 41-47, 2009. https://doi.org/10.1007/s00441-008-0659-8

FUCHS R, ELLINGER I: Endocytic and transcytotic processes in villous syncytiotrophoblast: Role in nutrient transport to the human fetus. Traffic 5: 725-738, 2004. https://doi.org/10.1111/j.1600-0854.2004.00221.x

GACHON AM, RICHARD J, DASTUGUE B: Human tears: normal protein pattern and individual protein determinations in adults. Curr Eye Res 2: 301-308, 1982. https://doi.org/10.3109/02713688209000774

GALLON M, CULLEN PJ: Retromer and sorting nexins in endosomal sorting. Biochem Soc Trans 43: 33-47, 2015. https://doi.org/10.1042/BST20140290

GESASE AP, SATOH Y: Apocrine secretory mechanism: recent findings and unresolved problems. Histol Histopathol 18: 597-608, 2003. 
GESASE AP, SATOH Y, ONO K: Secretagogue-induced apocrine secretion in the Harderian gland of the rat. Cell Tissue Res 285: 501-507, 1996. https://doi.org/10.1007/s004410050666

GONNELLA PA, NEUTRA MR: Membrane-bound and fluid-phase macromolecules enter separate prelysosomal compartments in absorptive cells of suckling rat ileum. J Cell Biol 99: 909-917, 1984. https://doi.org/10.1083/jcb.99.3.909

GURLT EF: Vergleichende Untersuchungen über die Haut des Menschen und der Haus-Säugethiere, besonders in Beziehung auf die Absonderungs-Organe des Haut-Talges und des Schweisses. Archiv für Anatomie, Physiologie und wissenschaftliche Medicin: 399-418, 1835.

HAMBURGER AE, BJORKMAN PJ, HERR AB: Structural insights into antibody-mediated mucosal immunity. Curr Top Microbiol Immunol 308: 173-204, 2006. https://doi.org/10.1007/3-540-30657-9_8

HARDER JJ: Glandula nova lachrymalis una cum ductu excretorio in cervis et damis. Acta Eruditorum Lipsiae: 49-52, 1694.

HE B, GUO W: The exocyst complex in polarized exocytosis. Curr Opin Cell Biol 21: 537-542, 2010. https://doi.org/10.1016/j.ceb.2009.04.007

HE W, LADINSKY M.S, HUEY-TUBMAN KE, JENSEN GJ, MCINTOSH JR, BJÖRKMAN PJ: FcRn-mediated antibody transport across epithelial cells revealed by electron tomography. Nature 455: 542-436, 2008. https://doi.org/10.1038/nature07255

HERMO L, DE MELO V: Endocytic apparatus and transcytosis in epithelial cells of the vas deferens in the rat. Anat Rec 217: 153-163, 1987. https://doi.org/10.1002/ar.1092170207

HERMO L, ADAMALI HI, ANDONIAN S: Immunolocalization of CA II and H+ V-ATPase in epithelial cells of the mouse and rat epididymis. J Androl 21: 376-391, 2000.

HERZENBERG H: Neue Beiträge zur Lehre von den apokrinen Schweissdrüsen. Virchows Arch Path Anat 266: 422-455, 1927. https://doi.org/10.1007/BF02126283

HOESSLI DC, SEMAC I, IQBAL A, NASIR-UD-DIN A, BORISCH B: Glycosphingolipid clusters as organizers of plasma membrane rafts and caveolate. Curr Org Chem 8: 439-452, 2004. https://doi.org/10.2174/1385272043485882

HOLMGREN E: Die Achseldrüsen des Menschen. Anat Anz 55: 553-566, 1922.

HORNER WE: Special Anatomy and Histology Vol. 1, 7th edition. Lea and Blanchard Press, Philadelphia, 1846.

HOWIE VM, PLOUSSARD JH, SLOYER JL, JOHNSTON RB JR: Immunoglobulins of the middle ear fluid in acute otitis media: relationship to serum immunoglobulin concentrations and bacterial cultures. Infect Immun 7: 589593, 1973. https://doi.org/10.1128/IAI.7.4.589-593.1973

HUNTER RH, CICINELLI E, EINER-JENSEN N: Peritoneal fluid as an unrecognised vector between female reproductive tissues. Acta Obstet Gynecol Scand 86: 260-265, 2007. https://doi.org/10.1080/00016340601155098

HURLEY HJ, SHELLEY WB: The role of myoepithelium of the human apocrine sweat gland. J Invest Derm 22: 143-155, 1954. https://doi.org/10.1038/jid.1954.19

ISHIKAWA T, BERNSTEIN J, REISMAN RE, ARBESMAN CE: Secretory otitis media: immunologic studies of middle ear secretions. J Allergy Clin Immunol 50: 319-325, 1972. https://doi.org/10.1016/00916749(72)90035-8

JAHN R: Principles of exocytosis and membrane fusion. Ann N Y Acad Sci 1014: 170-178, 2004. https://doi.org/10.1196/annals.1294.018

JANSSEN PT, VAN BIJSTERVELD OP: The relations between tear fluid concentrations of lysozyme, tear-specific prealbumin and lactoferrin. Exp Eye Res 36: 773-779, 1983. https://doi.org/10.1016/0014-4835(83)90031-3

JOHANNES L, LAMAZE C: Clathrin-dependent or not: Is it still the question? Traffic 3: 443-451, 2002. https://doi.org/10.1034/j.1600-0854.2002.30701.x

JONES EA JR, THOMAS LR, DAVIS NC: The significance of secretory IgA in middle ear fluid. Ann Allergy 42: 236-240, 1979.

KATO S: Über das Vorkommen apokriner Drusen in der Aussenhaut des Nasenflügels bei den Japanern. Okajimas Fol Anat Jap Bd 14: 97-100, 1936. https://doi.org/10.2535/ofaj1936.14.1 97 
KAUR R, KIM T, CASEY JR, PICHICHERO ME: Antibody in middle ear fluid of children originates predominantly from sera and nasopharyngeal secretions. Clin Vaccine Immunol 19: 1593-1596, 2012. https://doi.org/10.1128/CVI.05443-11

KAWABATA I, KUROSUMI K: Transmission and scanning electron microscopy of the human ceruminous apocrine gland. II. Myoepithelial cells. Arch Histol Jpn 39: 231-255, 1976. https://doi.org/10.1679/aohc1950.39.231

KLEINE-VEHN J, FRIML J: Polar targeting and endocytic recycling in auxin-dependent plant development. Annu Rev Cell Dev Biol 24: 447-473, 2008. https://doi.org/10.1146/annurev.cellbio.24.110707.175254

KLEINE-VEHN J, LEITNER J, ZWIEWKA M, SAUER M, ABAS L, LUSCHNIG C, FRIML J: Differential degradation of PIN2 auxin efflux carrier by retromer-dependent vacuolar targeting. Proc Natl Acad Sci USA 105: 17812-17817, 2008. https://doi.org/10.1073/pnas.0808073105

KOBAYASHI N, SUZUKI Y, TSUGE T, OKUMURA K, RA C, TOMINO Y: FcRn-mediated transcytosis of immunoglobulin $\mathrm{G}$ in human renal proximal tubular epithelial cells. Am J Physiol Ren Physiol 282: F358-F365, 2002. https://doi.org/10.1152/ajprenal.0164.2001

KOKOTOS AC, COUSIN MA: Synaptic vesicle generation from central nerve terminal endosomes. Traffic 16: 229-240, 2015. https://doi.org/10.1111/tra.12235

KOROLCHUK VI, SCHÜTZ MM, GÓMEZ-LLORENTE C, ROCHA J, LANSU NR, COLLINS SM, WAIRKAR YP, ROBINSON IM, O'KANE CJ: Drosophila Vps35 function is necessary for normal endocytic trafficking and actin cytoskeleton organisation. J Cell Sci 120: 4367-4376, 2007. https://doi.org/10.1242/jcs.012336

KUHN SH, ROSSOUW DJ, HOFFSTEIN S, FINKELSTEIN MC: Biochemical and morphologic changes in rabbit lung following endotracheal instillation of zymosan particles. Inflammation 7: 105-120, 1983. https://doi.org/10.1007/BF00917816

KUMAGAI N, BABA R, SAKUMA Y, ARITA K, SHINOHARA M, KOUROGI M, FUJIMOTO S, FUJITA M: Origin of the apical transcytic membrane system in jejunal absorptive cells of neonates. Med Mol Morphol 44: 71-78, 2011. https://doi.org/10.1007/s00795-010-0506-3

KUNO Y: Variations in secretory activity of human sweat glands. Lancet 231: 299-303, 1938. https://doi.org/10.1016/S0140-6736(00)62410-8

KUROSUMI K, KAWABATA I: Transmission and scanning electron microscopy of the human ceruminous apocrine gland. Arch Histol Jpn 40: 203-244, 1977. https://doi.org/10.1679/aohc1950.40.203

KVAINICKAS A, JIMENEZ-ORGAZ A, NÄGELE H, HU Z, DENGJEL J, STEINBERG F: Cargo-selective SNXBAR proteins mediate retromer trimer independent retrograde transport. J Cell Biol 16: 3677-3693, 2017. https://doi.org/10.1083/jcb.201702137

LAUDE AJ, PRIOR IA: Plasma membrane microdomains: Organization, function and trafficking (review). Mol Membr Biol 21: 193-205, 2004. https://doi.org/10.1080/09687680410001700517

LEITZELL K: Synaptotagmin: is 2 better than 1? J Neurosci 27: 4231-4232, 2007. https://doi.org/10.1523/JNEUROSCI.0668-07.2007

LIZANA J, ENEROTH P, BYSTRÖM B, BYGDEMAN M: Studies on the constancy of transudated and locally produced proteins in human seminal plasma. Int J Fertil 32: 71-76, 1987.

LODISH HF, BERK A, KAISER CA, KRIEGER M, BRETSCHER A, PLOEGH H, AMON A, SCOTT MP: Molecalur Cell Biology 6th edition. W H Freeman, New York, Basingstoke, 2013.

LOEB L: The cytology of the mammary gland. In: Special Cytology. EV COWDRY (ed), Hoeber, New York, 1932, pp 1633-1672.

LUTON F, CARDONE MH, ZHANG M, MOSTOV KE: Role of tyrosine phosphorylation in ligand-induced regulation of transcytosis of the polymeric Ig receptor. Mol Biol Cell 9: 1787-1802, 1998. https://doi.org/10.1091/mbc.9.7.1787

MA MH, LAIRD WA, SCOTT H: Cytopempsis of horseradish peroxidase in the hepatocyte. J Histochem Cytochem 22: 160-169, 1974. https://doi.org/10.1177/22.3.160

MACPHERSON AJ, UHR T: Compartmentalization of the mucosal immune responses to commensal intestinal bacteria. Ann N Y Acad Sci 1029: 36-43, 2004. https://doi.org/10.1196/annals.1309.005

MAJ M, WAGNER L, TRETTER V: 20 Years of secretagogin: exocytosis and beyond. Front Mol Neurosci 12: 29, 2019. https://doi.org/10.3389/fnmol.2019.00029 
MALMENDIER CL, AMERIJCKX JP: Apoprotein profile of plasma and chylous ascites lipoproteins. Clin Chim Acta 68: 259-269, 1976. https://doi.org/10.1016/0009-8981(76)90390-9

MATHIS J: Über Sekretionserscheinungen in Gallergdngen, zugleich ein Beitrag zur Lehre von der apokrinen Sekretionsart. Z mikr anat Forsch 10: 527-582, 1927.

McGOUGH IJ, CULLEN PJ: Recent advances in retromer biology. Traffic 12: 963-971, 2011. https://doi.org/10.1111/j.1600-0854.2011.01201.x

MCGOUGH IJ, STEINBERG F, GALLON M, YATSU A, OHBAYASHI N, HEESOM KJ, FUKUDA M, CULLEN PJ: Identification of molecular heterogeneity in SNX27-retromer-mediated endosome-to-plasma-membrane recycling. J Cell Sci 127: 4940-4953, 2014. https://doi.org/10.1242/jcs.156299

MELLADO M, CUARTERO Y BRUGADA R, VERGES M: Subcellular localisation of retromer in post-endocytic pathways of polarised Madin-Darby canine kidney cells. Biol Cell 106: 377-393, 2014. https://doi.org/10.1111/boc.201400011

MILOSEVIC I: Revisiting the role of clathrin-mediated endoytosis in synaptic vesicle recycling. Front Cell Neurosci 12: 27, 2018. https://doi.org/10.3389/fncel.2018.00027

MINAMITANI K: Über die Grosse der apokrinen Schweissdrüsen in der Aussenhaut des Nasenflügels bei den Chinesen. Okajimas Folia Anat Jap 20: 81-98, 1941a. https://doi.org/10.2535/ofaj1936.20.1 81

MINAMITANI K: Zytologische und histologische Untersuchungen der Schweissdrüsen in menschlicher Achselhaut (Über das Vorkommen der besonderen Formen der apokrinen und ekkrinen Schweissdrüsen in Achselhaut von Japanern. Okajimas Folia Anat Jap 20: 563-590, 1941b. https://doi.org/10.2535/ofaj1936.20.5-6_563

MINAMITANI K: Zytologische und histologische Untersuchungen der Schweissdrüsen in menschlicher Achselhaut (Zur Zytologie der apokrinen Schweissdrüsen in der menschlichen Achselhaut). Okajimas Folia Anat Jap 21: 61-94, 1941c. https://doi.org/10.2535/ofaj1936.21.1_61

MORGAN JR, COMSTRA HS, COHEN M, FAUNDEZ V: Presynaptic membrane retrieval and endosome biology: defining molecularly heterogeneous synaptic vesicles. Cold Spring Harb Perspect Biol 5: a016915, 2013. https://doi.org/10.1101/cshperspect.a016915

MORIYAMA G: Mikrochemische Untersuchung fiber die Achseldrüse, inbesondere Berücksichtigung der Osmidrosis axillae. Nagasaki Igakkai Zasshi 5: 302-310, 1927.

MUKHERJEE S, TESSEMA M, WANDINGER-NESS A: Vesicular trafficking of tyrosine kinase receptors and associated proteins in the regulation of signaling and vascular function. Circ Res 98: 743-756, 2006. https://doi.org/10.1161/01.RES.0000214545.99387.e3

MURRAY RZ, STOW JL: Cytokine Secretion in Macrophages: SNAREs, Rabs, and Membrane Trafficking. Front Immunol 5: 538, 2014. https://doi.org/10.3389/fimmu.2014.00538

OH P, MCINTOSH DP, SCHNITZER JE: Dynamin at the neck of caveolae mediates their budding to form transport vesicles by GTP-driven fission from the plasma membrane of endothelium. J Cell Biol 141: 101-114, 1998. https://doi.org/10.1083/jcb.141.1.101

OSEBOLD JW, MEDIN NI, ZEE YC: Immunochemical analysis of serum-related proteins in the respiratory tract secretions of normal mice. Infect Immun 12: 1141-1146, 1975. https://doi.org/10.1128/IAI.12.5.1141$\underline{1146.1975}$

OSHIKAWA T, BABA R, FUJITA M: Apical endocytosis of lectins by the absorptive cells of the suckling rat jejunum in vivo. Okajimas Folia Anat Jpn 73: 229-245, 1996. https://doi.org/10.2535/ofaj1936.73.5_229

PARR EL, BOZZOLA JJ, PARR MB: Immunity to vaginal infection by herpes simplex virus type 2 in adult mice: characterization of the immunoglobulins in vaginal mucus. J Reprod Immunol 38: 15-30, 1998. https://doi.org/10.1016/S0165-0378(97)00081-8

PARTON RG, JOGGERST B, SIMONS K: Regulated internalization of caveolae. J Cell Biol 127: 1199-1215, 1994. https://doi.org/10.1083/jcb.127.5.1199

PELKMANS L, HELENIUS A: Endocytosis via caveolae. Traffic 3: 311-320, 2002. https://doi.org/10.1034/j.1600$\underline{0854.2002 .30501 . \mathrm{x}}$ 
PETÄJÄ T, PEDERSEN C, PODER A, STRAUSS G, CATTEAU G, THOMAS F, LEHTINEN M, DESCAMPS D: Long-term persistence of systemic and mucosal immune response to HPV-16/18 AS04-adjuvanted vaccine in preteen/adolescent girls and young women. Int J Cancer 129: 2147-2157, 2011. https://doi.org/10.1002/ijc.25887

PLATZ F: Structural and experimental investigations of the functional anatomy and the turgor of the notochord in the larval tail of anuran tadpoles. Ann Anat 188: 289-302, 2006. https://doi.org/10.1016/j.aanat.2006.01.009

POCHA SM, WASSMER T, NIEHAGE C, HOFLACK B, KNUST E: Retromer controls epithelial cell polarity by trafficking the apical determinant Crumbs. Curr Biol 21: 1111-1117, 2011. https://doi.org/10.1016/j.cub.2011.05.007

PREDESCU SA, PREDESCU DN, MALIK AB: Molecular determinants of endothelial transcytosis and their role in endothelial permeability. Am J Physiol Lung Cell Mol Physiol 293: L823-842, 2007. https://doi.org/10.1152/ajplung.00436.2006

PRESTON JE, JOAN ABBOTT N, BEGLEY DJ: Transcytosis of macromolecules at the blood-brain barrier. Adv Pharmacol 71: 147-163, 2014. https://doi.org/10.1016/bs.apha.2014.06.001

PRIGENT-DELECOURT L, COFFIN B, COLOMBEL JF, DEHENNIN JP, VAERMAN JP, RAMBAUD JC: Secretion of immunoglobulins and plasma proteins from the colonic mucosa: an in vivo study in man. Clin Exp Immunol 99: 221-225, 1995. https://doi.org/10.1111/j.1365-2249.1995.tb05536.X

PURKYNĚ JE: Beobachtungen der spiralen Schweisscanäle der menschlichen Epidermis. Amtl Bericht über die Vers deutcher Naturf u Arzte zu Breslau 11: 59, 1833a.

PURKYNĚ JE: Beobachtungen der spiralen Schweisscanäle der menschlichen Epidermis. Notizen aus dem Gebiete der Natur- und Heilkunde (Froriep) Weimar 38: 152, 1833b.

RANVIER L: Sur la structure des glandes sudoripares. Compt Rend Acad Séanc Acad Sci (Paris) 89: 1120-1123, 1879.

RICHTER W: Beiträge zur normalen und pathologischen Anatomie der apokrinen Hautdrüsen des Menschen mit besonderer Berücksichtigung des Achselhöhlenorgans. Virch Arch 287: 277-296, 1932. https://doi.org/10.1007/BF01893195

RICHTER W, SCHMIDT W: Über das Vorkommen apokriner Drüsen in der Haut des Nasenflügels. Z mikr anat Forsch 35: 529-532, 1934.

RODMAN JS, MERCER RW, STAHL PD: Endocytosis and transcytosis. Curr Opin Cell Biol 2: 664-672, 1990. https://doi.org/10.1016/0955-0674(90)90108-Q

ROJAS R, APODACA G: Immunoglobulin transport across polarized epithelial cells. Nat Rev Mol Cell Biol 3: 944-955, 2002. https://doi.org/10.1038/nrm972

RUTTER GA, TSUBOI T: Kiss and run exocytosis of dense core secretory vesicles. Neuroreport 15: 79-81, 2004. https://doi.org/10.1097/00001756-200401190-00016

SCHIEFFERDECKER P: Die Hautdrüsen des Menschen und der Säugetiere. Biol Zentralbl 37: 11-12, 1917.

SCHIEFFERDECKER P: Über morphologische Sekretionserscheinungen in den ekkrinen Hautdrüsen des Menschen. Arch Dermatol Syphilis 132: 130-132, 1921. https://doi.org/10.1007/BF01843885

SCHIEFFERDECKER P: Die Hautdrüsen des Menschen und der Säugetiere, ihre biologische und rassenanatomische Bedeutung, sowie die Muscularis sexualis. Zoologica (Stuttgart) 72: 1-154, 1922.

SCHNEIDER YJ, TULKENS P, DE DUVE C, TROUET A: Fate of plasma membrane during endocytosis. II. Evidence for recycling (shuttle) of plasma membrane constituents. J Cell Biol 82: 466-474, 1979. https://doi.org/10.1083/jcb.82.2.466

SCHORN K, HOCHSTRASSER K, PASEMANN V: Rate of transudation of the mucous membranes by testing the enzymes of the intermediary metabolism in the secretion of patients with different internal diseases. Laryngol Rhinol Otol (Stuttg) 54: 659-662, 1975.

SCHNITZER JE, LIU J, OH P: Endothelial caveolae have the molecular transport machinery for vesicle budding, docking, and fusion including VAMP, NSF, SNAP, annexins, and GTPases. J Biol Chem 270: 14399-14404, 1995. https://doi.org/10.1074/jbc.270.24.14399

SCHUMACHER GF: Biochemistry of cervical mucus. Fertil Steril 21: 697-705, 1970. https://doi.org/10.1016/S0015$\underline{0282(16) 37800-1}$ 
SCHWARZ TF, KOCKEN M, PETÄJÄ T, EINSTEIN MH, SPACZYNSKI M, LOUWERS JA, PEDERSEN C, LEVIN M, ZAHAF T, PONCELET S, HARDT K, DESCAMPS D, DUBIN G: Correlation between levels of human papillomavirus (HPV)-16 and 18 antibodies in serum and cervicovaginal secretions in girls and women vaccinated with the HPV-16/18 AS04-adjuvanted vaccine. Hum Vaccin 6: 1054-1061, 2010. https://doi.org/10.4161/hv.6.12.13399

SELINGER DS, SELINGER RC, REED WP: Resistance to infection of the external eye: the role of tears. Surv Ophthalmol 24: 33-38, 1979. https://doi.org/10.1016/0039-6257(79)90145-0

SHEN J, ZHAO Q, WANG X, GAO C, ZHU Y, ZENG Y, JIANG L: A plant Bro1 domain protein BRAF regulates multivesicular body biogenesis and membrane protein homeostasis. Nat Commun 9: 3784, 2018. https://doi.org/10.1038/s41467-018-05913-y

SIMIONESCU M, GAFENCU A, ANTOHE F: Transcytosis of plasma macromolecules in endothelial cells: a cell biological survey. Microsc Res Tech 57: 269-288, 2002. https://doi.org/10.1002/jemt.10086

SIMONETTI B, DANSON CM, HEESOM KJ, CULLEN PJ: Sequence-dependent cargo recognition by SNX-BARs mediates retromer-independent transport of CI-MPR. J Cell Biol 216: 3695-3712, 2017. https://doi.org/10.1083/jcb.201703015

SNYDER DA, KELLY ML, WOODBURY DJ: SNARE complex regulation by phosphorylation. Cell Biochem Biophys 45: 111-123, 2006. https://doi.org/10.1385/CBB:45:1:111

STAN RV: Structure of caveolae. Biochim Biophys Acta - Mol Cell Res 1746: 334-348, 2005. https://doi.org/10.1016/j.bbamcr.2005.08.008

STAUBESAND J: Cytopempsis. In: Sekretion und Exkretion Funktionelle und morphologische Organisation der Zelle. Springer-Verlag, Berlin Heidelberg, New York, 1965, p. 162-189. https://doi.org/10.1007/978-3-642-929083 11

SÜDHOF TC: The synaptic vesicle cycle. Annu Rev Neurosci 27: 509-547, 2004. https://doi.org/10.1146/annurev.neuro.26.041002.131412

SÜDHOF TC, ROTHMAN JE: Membrane fusion: grappling with SNARE and SM proteins. Science 323: 474-477, 2009. https://doi.org/10.1126/science. 1161748

SUN Y, HU G, ZHANG X, MINSHALL RD: Phosphorylation of caveolin-1 regulates oxidant-induced pulmonary vascular permeability via paracellular and transcellular pathways. Circul Res 105: 676-685, 2009. https://doi.org/10.1161/CIRCRESAHA.109.201673

TAUBER PF, ZANEVELD LJ, PROPPING D, SCHUMACHER GF: Components of human split ejaculates. I. Spermatozoa, fructose, immunoglobulins, albumin, lactoferrin, transferrin and other plasma proteins. J Reprod Fertil 43: 249-267, 1975. https://doi.org/10.1530/jrf.0.0430249

TESTA-RIVA F, PUXEDDU P: Secretory mechanisms of human ceruminous glands: A transmission and scanning electron microscopic study. Anatomical Record 196: 363-372, 1980. https://doi.org/10.1002/ar.1091960402

THOMSEN P, ROEPSTORFF K, STAHLHUT M, VAN DEURS B: Caveolae are highly immobile plasma membrane microdomains, which are not involved in constitutive endocytic trafficking. Mol Biol Cell 13: 238-250, 2002. https://doi.org/10.1091/mbc.01-06-0317

THORN L, SCHINKO I, WETZSTEIN R: Light and electron microscopy studies of the development of Reissner's membrane in the cochlear duct of guinea pig fetuses. [Article in German] Arch Otorhinolaryngol 237: 243-254, 1983. https://doi.org/10.1007/BF00453729

VAN WEERING JRT, VERKADE P, CULLEN PJ: SNX-BAR proteins in phosphoinositide-mediated, tubular-based endosomal sorting. Semin Cell Devel Biol 21: 371-380, 2010. https://doi.org/10.1016/j.semcdb.2009.11.009

VENKATARAMI RK, GOVINDAPPA S: Pattern of protein profiles of reproductive organs after induced bilateral cryptorchidism in albino rats. Arch Int Physiol Biochim 93: 25-32, 1985. https://doi.org/10.3109/13813458509104512

VERGÉS M: Retromer: multipurpose sorting and specialization in polarized transport. Int Rev Cell Mol Biol 271: 153-198, 2008. https://doi.org/10.1016/S1937-6448(08)01204-5

VERGÉS M: Retromer in polarized protein transport. Int Rev Cell Mol Biol 323: 129-179, 2016. https://doi.org/10.1016/bs.ircmb.2015.12.005 
VERGÉS M, LUTON F, GRUBER C, TIEMANN F, REINDERS LG, HUANG L, BURLINGAME AL, HAFT CR, MOSTOV KE: The mammalian retromer regulates transcytosis of the polymeric immunoglobulin receptor. Nat Cell Biol 6: 763-769, 2004. https://doi.org/10.1038/ncb1153

VERGÉS M, SEBASTIAN I, MOSTOV KE: Phosphoinositide 3-kinase regulates the role of retromer in transcytosis of the polymeric immunoglobulin receptor. Exp Cell Res 313: 707-718, 2007. https://doi.org/10.1016/j.yexcr.2006.11.010

VILLASEÑOR R, SCHILLING M, SUNDARESAN J, LUTZ Y, COLLIN L: Sorting Tubules Regulate Blood-Brain Barrier Transcytosis. Cell Rep 21: 3256-3270, 2017. https://doi.org/10.1016/j.celrep.2017.11.055

VLACHOGIANNAKOS J, VIAZIS N, VASIANOPOULOU P, VAFIADIS I, KARAMANOLIS DG, LADAS SD: Long-term administration of rifaximin improves the prognosis of patients with decompensated alcoholic cirrhosis. J Gastroenterol Hepatol 28: 450-455, 2013. https://doi.org/10.1111/jgh.12070

VOGEL L, SCHOONBROOD D, GELUK F, HOEK F, BRESSER P, OUT T, JANSEN H, DANKERT J, VAN ALPHEN L: Iron-binding proteins in sputum of chronic bronchitis patients with Haemophilus influenzae infections. Eur Respir J 10: 2327-2333, 1997. https://doi.org/10.1183/09031936.97.10102327

WASSMER T, ATTAR N, HARTERINK M, VAN WEERING JR, TRAER CJ, OAKLEY J, GOUD B, STEPHENS DJ, VERKADE P, KORSWAGEN HC, CULLEN PJ: The retromer coat complex coordinates endosomal sorting and dynein-mediated transport, with carrier recognition by the trans-Golgi network. Dev Cell 17: 110-122, 2009. https://doi.org/10.1016/j.devcel.2009.04.016

WEISS J: Occurrence and ultrastructure of mast cells in the hypothalamus of teleost fishes. [Article in German] Z Mikrosk Anat Forsch 93: 147-160, 1979.

WENDT A: De epidermide humana. Dissertatio inauguralis anatomica $4^{\circ}$. pag. VI +36 . Accedit tabula aenea. Universitas Vratislaviae, 1833.

WENDT A: Über die menschliche Epidermis. Archiv für Anatomie, Physiologie und wissenschaftliche Medicin: 278-291, 1834.

WESTERINK RH: Targeting exocytosis: ins and outs of the modulation of quantal dopamine release. CNS Neurol Disord Drug Targets 5: 57-77, 2006. https://doi.org/10.2174/187152706784111597

WOLF J: Oberflächenrelief der menschlichen Haut. Z mikr anat Forsch 47: 351-400, 1940.

ZHOU B, WU Y, LIN X: Retromer regulates apical-basal polarity through recycling Crumbs. Dev Biol 360: 87-95, 2011. https://doi.org/10.1016/j.ydbio.2011.09.009

ZUBER B, LUČIĆ V: Molecular architecture of the presynaptic terminal. Curr Opin Struct Biol 54: 129-138, 2019. https://doi.org/10.1016/j.sbi.2019.01.008 